\title{
Phenethicillin Potassium
}

National Cancer Institute

\section{Source}

National Cancer Institute. Phenethicillin Potassium. NCI Thesaurus. Code C84048.

The potassium salt form of phenethicillin, a narrow-spectrum, beta-lactamase-sensitive penicillin with antibacterial activity. Phenethicillin binds to and inactivates the penicillin binding proteins (PBPs) located inside the bacterial cell wall. Inactivation of PBPs interferes with the cross-linkage of peptidoglycan chains necessary for bacterial cell wall strength and rigidity. This interrupts bacterial cell wall synthesis and results in the weakening of the bacterial cell wall, eventually causing cell lysis. 